\title{
PENGARUH PENGELOLAAN KEUANGAN TENAGA KERJA MUDA PADA KOTA AMPANA
}

\author{
Mardiana $^{1}$, Sefti Husna Luthfiyah ${ }^{2}$, Wyne Febrianti ${ }^{3}$ \\ ${ }^{123}$ Fakultas Ekonomi dan Bisnis Universitas Raharja \\ Email: mardiana@raharja.info
}

\begin{abstract}
Abstrak
Masyarakat dengan latar belakang pengetahuan keuangan yang baik akan sadar dan lebih mementingkan prioritas. Namun tidak menutup kemungkinan jika masyarakat dengan tingkat pendidikan yang tinggi dan kondisi finansial yang mapan akan membelanjakan uangnya secara berlebihan tanpa adanya perhitungan dengan baik karena mereka terdesak dengan gaya hidup yang ada pada lingkungannya. Oleh karena itu penelitian ini bertujuan untuk mengetahui bagaimana pengaruh gaya hidup, pendapatan, kepribadian dan literasi keuangan terhadap pengelolaan keuangan. Penelitian ini dilakukan di Kota Ampana dengan jumlah sampel sebanyak 159 responden. Teknik pengambilan sampel menggunakan teknik probability sampling dengan metode stratified random sampling. Metodologi penelitian menggunakan pendekatan kuantitatif dan metode survey dan analisis linear regresi berganda untuk menguji hipotesis. Hasilnya menunjukkan semua variabel independen berpengaruh terhadap variabel dependen, faktor gaya hidup memiliki pengaruh tertinggi terhadap pengelolaan keuangan. Kemudian nilai $R$ Square menunjukkan sebesar 0.068 atau $68 \%$ secara keseluruhan mempengaruhi pengelolaan keuangan, sedangkan sisanya $32 \%$ dipengaruhi oleh faktor lain.
\end{abstract}

Kata kunci: pengelolaan keuangan, gaya hidup, pendapatan, kepribadian, literasi keuangan, tenaga kerja muda

\section{Abstract}

Citizens with a good background in financial knowledge will be aware of and prioritize priorities. However, it is possible that people with a high level of education and well-established financial conditions will spend their money excessively without proper calculations because they are pressured by the lifestyle that exists in their environment. Therefore, this study aims to determine the influence of lifestyle, income, personality and financial literacy on financial management. This research was conducted in Ampana City with a total sample of 159 respondents. The sampling technique used a probability sampling technique with a stratified random sampling method. The results show that all independent variables have an effect on the dependent variable, wherein lifestyle factors have the highest influence on financial management. Then the $R$ Square value shows 0.068 or $68 \%$ overall affecting financial management, while the remaining $32 \%$ is influenced by other factors.

Keywords: financial management, lifestyle, income, personality, financial literacy, young workforce

\section{Pendahuluan}

Kaum muda seperti yang dikelompokkan oleh Badan Pusat Statistik (2015-2019) dalam situs resminya yaitu bps.go.id adalah mereka yang berusia 12-24 tahun. Akan tetapi pemahaman internasional, kelompok usia yang digunakan untuk mengklasifikasikan orang muda adalah remaja berusia 12-25 tahun dan dewasa muda 26-45. Dalam proposal penelitian ini, yang dimaksud dengan usia muda adalah 
penduduk dengan usia 15-35 tahun yang dalam demografi, komposisi penduduk menurut kelompok umur dan jenis kelamin berpengaruh terhadap kondisi penduduk dimasa yang akan datang. Makanya, perilaku money management saat ini tahap formatif kehidupan merupakan pertimbangan penting bagi pemerintah, lembaga keuangan dan lembaga publik.

\section{Gambar 1. Proyeksi Jumlah Penduduk Indonesia Menurut Kelompok Usia (2015-} 2045)

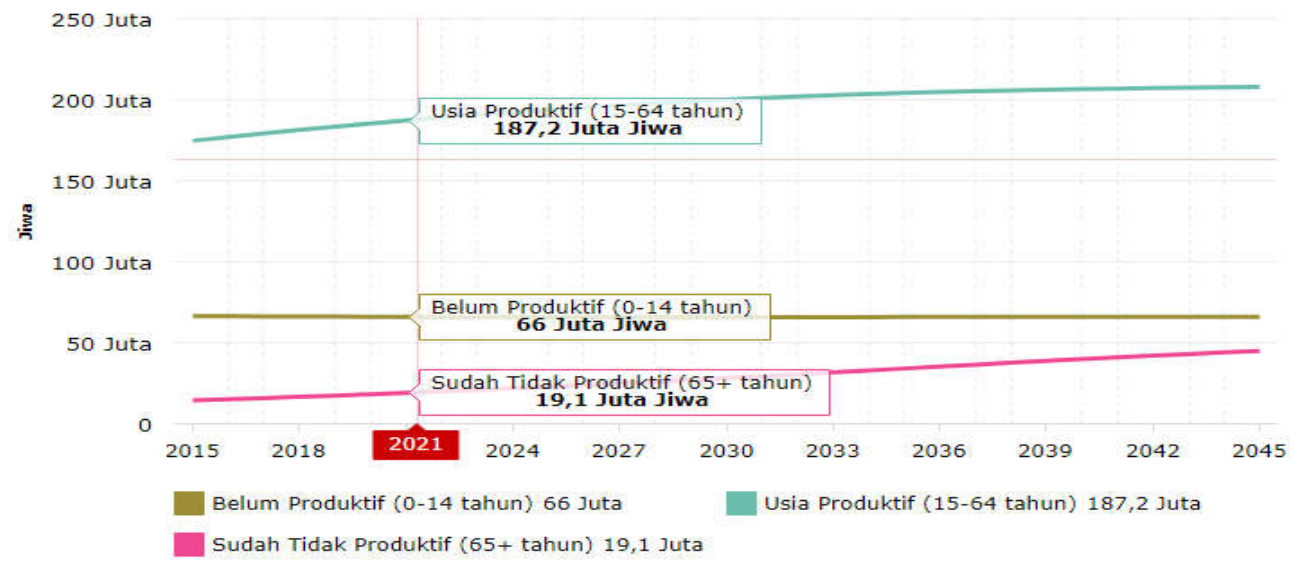

Sumber: BPS, 2018

Mayoritas penduduk muda tersebut hidup di negara-negara berkembang. Menurut Sensus Penduduk Antar Sensus (Supas 2015 edisi revisi) jumlah penduduk Indonesia akan mencapai 269,6 juta jiwa pada 2020 Jumlah penduduk Indonesia mencapai 187,6 juta jiwa pada 2020. Jumlah tersebut terdiri atas kategori usia belum produktif (0-14 tahun) sebanyak 66,07 juta jiwa, usia produktif (15-64 tahun) 185,34 juta jiwa, dan usia sudah tidak produktif (65+ tahun) 18,2 juta jiwa. Jumlah penduduk Indonesia diproyeksikan terus bertambah menjadi 318,96 juta pada 2045. Berdasarkan data tersebut, Indonesia akan mengalami masa bonus demografi hingga 2045. Di mana jumlah penduduk usia produktif lebih banyak dibandingkan penduduk tidak produktif (belum produktif dan sudah tidak produktif). Jumlah usia produktif pada 2020 mencapai $68,75 \%$ dari total populasi. Melimpahnya sumber daya manusia usia produktif ini hendaknya dapat dimanfaatkan dengan peningkatan kualitas, baik pendidikan maupun keterampilan guna menyongsong era industri 4.0. Dengan jumlah penduduk usia produktif yang lebih besar tersebut maka angka ketergantungan penduduk (dependency ratio) Indonesia sebesar 45,46. Artinya, setiap 100 penduduk usia produktif memiliki tanggungan 46 jiwa penduduk usia tidak produktif. Besarnya angka penduduk usia muda ini tidak terlepas dari penurunan angka kelahiran maupun tingkat kesuburan serta peningkatan penduduk usia kerja. Dari perspektif demografis, besarnya penduduk usia muda dapat berfungsi sebagai mesin penggerak perekonomian. Usia muda, khususnya pada usia produktif, dianggap secara fisik dan mental seharusnya mampu melakukan kegiatan ekonomi yang menggerakkan perekonomian bangsa. Dalam proses pemenuhan kebutuhan tersebut, 
akan dipengaruhi oleh kondisi sosial sekitar yang akhirnya akan menimbulkan suatu pola gaya hidup baru yang secara pasti akan memengaruhi kehidupan. Mowen dan Michael (2008 : 117) mendefinisikan bahwa gaya hidup akan mempengaruhi perilaku seseorang yang pada akhirnya menentukan pola konsumsi seseorang.

Dengan adanya gaya hidup baru di masyarakat maka tidak sedikit generasi muda sebagai mesin pendorong leisure economy berusaha memenuhi kebutuhan leisure dan pengalaman tersebut sehingga mengesampingkan kebutuhan dasar lainnya. Hal ini dikarenakan bertambahnya jumlah pengeluaran yang harus dikeluarkan namun tidak diikuti dengan kenaikan jumlah pendapatan yang diperoleh (Yushita, 2017 : 14). Badan Pusat Statistik (BPS) mencatat rata-rata orang Indonesia menghabiskan lima besar pengeluaran bukan makanan didominasi oleh biaya perumahan pembelian BBM, listrik, kendaraan, dan pulsa ponsel. Konsumsi bukan makanan sendiri paling banyak terjadi di perkotaan dengan persentase 55,43\%, dan sisanya baru untuk membeli makanan. Sementara di pedesaan, 55,83\% uang yang berputar dibelanjakan makanan sedangkan belanja bukan makanan hanya 44,17\% . Persentase konsumsi bukan makanan semakin tinggi di kota-kota besar. DKI Jakarta yang menjadi pengonsumsi bukan makanan terbesar bisa memiliki persentase mencapai $63,11 \%$. Sedangkan kota yang mengonsumsi bukan makanan terkecil berada di D.I Aceh.

Pengetahuan keuangan yang baik secara subjektif dan objektif berpengaruh terhadap perilaku keuangan secara signifikan dan pengetahuan keuangan merupakan prediktor utama dalam membentuk perilaku keuangan (Universitas Pendidikan Undiksha, 2015 : 67). Kemampuan seseorang dalam melakukan perencanaan, pengelolaan serta pengendalian keuangan erat kaitannya dengan pengetahuan seseorang tersebut terhadap konsep literasi keuangan.

Masyarakat dengan latar belakang pengetahuan keuangan yang baik akan sadar dan lebih mementingkan prioritas. Namun tidak menutup kemungkinan jika masyarakat dengan tingkat pendidikan yang tinggi dan kondisi finansial yang mapan akan membelanjakan uangnya secara berlebihan tanpa adanya perhitungan dengan baik karena mereka terdesak dengan gaya hidup yang ada pada lingkungannya. Rendahnya tingkat literasi keuangan masyarakat juga menjadi penyebab tidak berjalan dengan baik sebuah pengelolaan keuangan. Literasi keuangan menjadi sangat penting karena merupakan sebuah landasan kritis bagi seseorang untuk pengambilan keputusan pembelian sesuatu. Berdasarkan fenomena dan juga penelitian-penelitian yang mendukung dan menolak seperti diuraikan diatas, maka peneliti tertarik untuk melakukan penelitian ini dengan harapan dapat membawa pertumbuhan ekonomi kearah yang positif.

\subsection{Pengelolaan Keuangan}

\section{Kajian Pustaka}

Pengelolaan keuangan merupakan bagian dari kegiatan manajemen keuangan pribadi yang merupakan proses seorang individu memenuhi kebutuhan hidup melalui kegiatan mengelola sumber keuangan secara tersusun dan sistematis. Sina (2012 : 172-173) menjelaskan bahwa pengelolaan keuangan merupakan kemampuan membuat suatu pertimbangan atau melakukan investasi di masa depan. Dengan 
perencanaan dan pengelolaan investasi yang baik dan benar akan mencapai ketentraman dan kenyamanan dalam hidup (Yulianti \& Silvy, 2013 : 60). Menurut J. L. Massie (2001) manajemen keuangan adalah kegiatan operasional bisnis yang bertanggung jawab untuk memperoleh dan menggunakan dana yang diperlukan untuk sebuah operasi yang efektif dan efisien. Menurut Howard \& Upton manajemen keuangan adalah penerapan fungsi perencanaan \& pengendalian fungsi keuangan. Menurut Emery et al (2004) manajemen keuangan merupakan suatu bidang keuangan yang menerapkan prinsip-prinsip keuangan dalam sebuah organisasi untuk menciptakan dan mempertahankan nilai melalui pengambilan keputusan dan manajemen sumber daya yang tepat. Menurut Bodie, Kane dan Marcus (2008 : 388) prospect theory memodifikasi deskripsi analitik dari investor risk averse rasional yang ditemukan dalam teori keuangan standar. Dalam hal ini prospect theory berhubungan dengan sikap pengambilan keputusan seseorang yang tidak hanya berdasarkan pertimbangan rasional tetapi aspek emosional juga berpengaruh di dalamnya. Dalam kondisi ketidakpastian individu akan memutuskan berdasarkan pertimbangan untung dan rugi. Pembuatan keputusan dalam kondisi ketidakpastian ini disebut dengan prospect theory. Keputusan tersebut dapat berubah jika terpaksa harus merubahnya karena dalam prospect theory akan mempertimbangkan titik referensi dari segala sudut.

\subsection{Gaya Hidup}

Menurut Sugihartati (2010 : 159) gaya hidup adalah cara hidup mencakup sekumpulan kebiasaan, pandangan dan pola-pola respon terhadap hidup, serta terutama perlengkapan untuk hidup. Gaya hidup juga merupakan cara bagaimana seseorang hidup, termasuk bagaimana seseorang menggunakan uangnya, bagaimana ia mengalokasikan waktunya dan sebagainya (Kanserina, 2015 : 3). Sunarto (2003 : 103) gaya hidup adalah pola kehidupan seseorang untuk memahami kekuatankekuatan ini kita harus mengukur dimensi AIO utama konsumen aktivitas (pekerjaan, hobi, belanja, olahraga, kegiatan sosial), minat (makanan, mode, keluarga, rekreasi), pendapat (mengenai diri mereka sendiri, masalah-masalah sosial, bisnis, produk).

\subsection{Pendapatan}

Besarnya hasrat individu untuk memenuhi kebutuhan hidup sesuai dengan tingkat pendapatan perkapita adalah pemicu munculnya financial management behavior. Menurut pendapat lain, pendapatan adalah kenaikan kotor dalam aset atau penurunan dalam liabilitas atau gabungan dari keduanya selama periode yang dipilih oleh pernyataan pendapatan yang berakibat dari investasi yang halal, keuntungan, seperti manajemen rekening investasi terbatas. (Antonio,2001 : 204 ). Menurut PSAK No. 23 Paragraf 06 Ikatan Akuntan Indonesia : Pendapatan adalah sebuah arus kas masuk bruto dari manfaat ekonomi yang timbul dari aktivitas perusahaan yang normal pada suatu periode dimana arus masuk tersebut dapat mempengaruhi pada kenaikan ekuitas yang tidak berasal kontribusi penanam modal. Menurut Kieso, Warfield dan Weygantd (2011:955) Pendapatan merupakan segala arus masuk bruto dari manfaat ekonomi yang muncul dari kegiatan normal entitas pada satu periode jika arus masuk itu berakibat terjadinya kenaikan ekuitas yang tidak berasal dari penanam modal. 


\subsection{Kepribadian}

Terdapat variabel lain yang dipertimbangkan dari segi psikologis yang juga dapat mempengaruhi perilaku manajemen keuangan adalah variabel kepribadian. Menurut Sina (2014), memahami aspek kepribadian dalam mengelola keuangan dibutuhkan untuk sukses mengelola keuangan karena setiap tipe kepribadian berbeda dalam cara mengelola keuangannya. Setelah dilakukan analisis mendalam, ditemukan beberapa masing-masing tipe kepribadian yang akan menyebabkan masalah keuangan seperti salah satunya adalah utang yang berlebihan. Berbagai peneliti keuangan juga menemukan bahwa aspek kepribadian juga turut mempengaruhi kesuksesan seseorang dalam mengelola keuangannya. Kepribadian (Personality) Menurut Feist (2010: 3) kepribadian adalah suatu pola watak yang relatif permanen, dan sebuah karakter unik yang memberikan konsistensi sekaligus individualitas bagi perilaku seseorang. Sedangkan menurut Erich Fromm dalam Alma (2013: 78) kepribadian adalah merupakan keseluruhan kualitas psikis yang diwarisi atau diperoleh yang khas pada seseorang yang membuatnya unik. Selain itu Sjarkawi (2006:11) berpendapat bahwa kepribadian adalah ciri atau karakteristik atau gaya atau sifat khas dari diri seseorang yang bersumber dari bentukan bentukan yang diterima dari lingkungan. Adapun menurut Yusuf (2008:5) menjelaskan bahwa kepribadian merupakan seperangkat asumsi tentang kualitas tingkah laku manusia beserta definisi empirisnya. Menurut M.A.W.Brower kepribadian adalah corak tingkah laku sosial individu yaitu meliputi keinginan, opini, dorongan dan kekuatan serat perilaku-perilaku seseorang. Menurut Theodore R Newcombe kepribadian adalah organisasi sikap-sikap yang dimiliki seseorang sebagai latar belakang terhadap perilaku.

\subsection{Literasi Keuangan}

Menurut OJK Literasi Keuangan adalah pengetahuan dan keyakinan tentang lembaga jasa keuangan serta produk jasa keuangan, termasuk fitur, manfaat dan risiko, hak dan kewajiban terkait produk dan jasa keuangan, serta memiliki keterampilan dalam menggunakan produk dan jasa keuangan. Otoritas Jasa Keuangan (OJK) mendorong masyarakat agar memahami dan mengerti akan literasi keuangan. Hal ini mengingat angka tingkat literasi keuangan masyarakat Indonesia masih jauh jika dibandingkan dengan inklusi keuangan. Masyarakat yang paham produk keuangan atau jasa keuangan baru sedikit. Dan lebih lagi, masyarakat sudah beli produk keuangan tapi tidak paham. Ibaratnya sudah masuk tapi tidak mengerti apa-apa. Karena itu, OJK memiliki komitmen bersama-sama para pelaku usaha jasa keuangan untuk meningkatkan literasi dan inklusi keuangan serta perlindungan konsumen. Dengan begitu, diharapkan tingkat inklusi keuangan meningkat serta program perlindungan konsumen terlaksana sesuai dengan yang ditargetkan. Dengan meningkatnya inklusi keuangan dan perlindungan konsumen diharapkan dapat membawa pertumbuhan ekonomi kearah yang positif. DNKI menetapkan target dan Program Kerja SNKI 2021-2024 dalam Rapat Koordinasi SNKI. Target indeks inklusi keuangan tahunan 2021-2024 yang ditetapkan masing-masing sebesar $82 \%$ pada tahun $2021,85 \%$ pada tahun 2022, 88\% pada tahun 2023 dan 90\% pada tahun 2024. Peraturan Otoritas 
Jasa Keuangan Nomor 76 Tahun 2016 mendefinisikan bahwa literasi keuangan adalah pengetahuan (knowledge), keterampilan (skill) dan keyakinan (confidence) yang mempengaruhi sikap dan perilaku untuk meningkatkan kualitas pengambilan keputusan dan pengelolaan keuangan dalam rangka mencapai kesejahteraan. Organization for Economic Cooperation and Development (OECD) mendefinisikan literasi keuangan sebagai kombinasi 3 kesadaran, pengetahuan, keterampilan, sikap dan perilaku yang dibutuhkan untuk membuat keputusan keuangan yang sehat sehingga dapat mencapai kesejahteraan keuangan individu (Atkinson dan Messy, 2012:14). Literasi keuangan dapat diartikan sebagai pengetahuan keuangan yang bertujuan untuk mencapai kesejahteraan, didefinisikan oleh Lusardi \& Mitchell (2014 : 2). Menurut Yushita (2017 : 16) literasi keuangan adalah kemampuan yang mencakup untuk membedakan pilihan keuangan, membahas uang dan masalah keuangan tanpa ketidaknyamanan, merencanakan masa depan, dan menanggapi kompeten untuk peristiwa kehidupan yang mempengaruhi keputusan keuangan sehari-hari, termasuk peristiwa di ekonomi secara umum. Literasi keuangan memiliki beberapa komponen untuk mengukur tingkat literasi keuangan seseorang, sesuai definisinya berikut beberapa komponen literasi keuangan:

1. Pengetahuan Keuangan (Financial Knowledge) Soetiono dan Setiawan (2018) menyatakan bahwa tingkat pengetahuan atau pemahaman (financial knowledge) berkaitan dengan pengetahuan mengenai lembaga jasa keuangan formal, produk dan layanan jasa lembaga keuangan, pengetahuan terkait dengan delivery channel dan karakteristik produk.

2. Perilaku Keuangan (Financial Behavior) berhubungan dengan tujuan menggunakan produk dan upaya mencapai tujuan keuangan (Soetiono dan Setiawan, 2018:47). (Hilgert, 2003:310) menyatakan bahwa perilaku keuangan seseorang akan tampak dari seberapa bagus seseorang mengelola uang kas, mengelola utang, tabungan dan pengeluaran - pengeluaran lainnya. Studi yang dilakukan oleh Sakinah dan Mudzakir menggunakan tiga komponen literasi keuangan yaitu financial knowledge, financial attitude dan financial behavior.

Sikap Keuangan (Financial Attitude) Sikap keuangan berhubungan dengan tujuan keuangan dan penyusunan rencana keuangan pribadi. financial attitude tercermin dalam enam konsep berikut (Furnham, 1984) : a) Obsession, merujuk pada pola pikir seseorang tentang uang dan persepsinya tentang masa depan untuk mengelola uang dengan baik. b) Power, yaitu merujuk pada seseorang yang menggunakan uang sebagai alat untuk mengendalikan orang lain dan menurutnya uang dapat menyelesaikan masalah. c) Effort, merujuk pada seseorang yang merasa pantas memiliki uang dari apa yang sudah dikerjakannya. d) Inadequacy, merujuk pada seseorang yang selalu merasa tidak cukup memiliki uang. e) Retention, merujuk pada seseorang yang memiliki kecenderungan tidak ingin menghabiskan uang. f) Security, merujuk pada pandangan seseorang yang sangat kuno tentang uang, seperti anggapan bahwa uang lebih baik hanya disimpan sendiri tanpa ditabung di bank atau untuk investasi. 4. Keterampilan Keuangan (Financial Skill) Berkaitan dengan kemampuan menghitung produk dan jasa lembaga keuangan, seperti bunga (tabungan atau pinjaman), hasil investasi, biaya dan denda (Soetiono dan Setiawan, 2018:47). Survei yang dilakukan OJK menggunakan tiga komponen literasi keuangan yang terdiri dari 
tingkat 6 pengetahuan, keterampilan keuangan, dan kepercayaan terhadap lembaga keuangan. 5. Tingkat Keyakinan Keuangan (confidence) Berkaitan dengan pengetahuan mengenai lembaga keuangan, produk dan layanan jasa keuangan serta kepercayaan terhadap lembaga jasa keuangan (Soetiono dan Setiawan, 2018:47). Studi sebelumnya telah menyinggung mengenai beberapa komponen literasi keuangan, maka dapat disimpulkan bahwa komponen literasi keuangan tersebut dapat dibagi menjadi sisi pengetahuan, sisi kemampuan, sisi keterampilan dan sisi kepercayaan seperti yang tergambar pada bagan berikut

\section{Metode}

Sumber data yang digunakan dalam penelitian ini adalah sumber data primer dengan metode pengumpulan data menggunakan kuesioner kepada 159 responden secara online kepada tenaga kerja muda di Kota Ampana. Metode analisis data yang digunakan dalam penelitian ini adalah metode analisis kuantitatif. Regresi berganda dilakukan terhadap model lebih dari satu variabel bebas untuk diketahui pengaruhnya terhadap variabel terikat. Penelitian ini menggunakan alat bantu program statistik SPSS for windows untuk mempermudah proses pengolahan data-data penelitian dari program tersebut akan didapatkan output berupa hasil pengolahan dari data yang telah dikumpulkan, kemudian output hasil pengolahan data tersebut diinterpretasikan akan dilakukan analisis terhadapnya. Setelah dilakukan analisis kemudian diambil kesimpulan sebagai sebuah hasil dari penelitian. Regresi berganda dilakukan untuk mengetahui sejauh mana variabel bebas mempengaruhi variabel terikat, dapat disusun dalam fungsi atau persamaan sebagai berikut: Persamaan umumnya adalah:

$$
\mathrm{Y}=\alpha+b_{1} \mathrm{X} 1+\mathrm{b}_{2} \mathrm{X} 2+\mathrm{b}_{3} \mathrm{X} 3+\mathrm{b}_{4} \mathrm{X} 4+\mathrm{e}
$$

Keterangan :

$\mathrm{Y}=$ Pengelolaan Keuangan

$\mathrm{a}=$ Konstanta

$\mathrm{b}=$ Koefisien regresi variabel bebas

X1= Gaya Hidup

$\mathrm{X} 2=$ Pendapatan

X3 $=$ Kepribadian

X4= Literasi Keuangan

$\mathrm{E}=$ Error

\section{Uji Validitas}

\section{Hasil Dan Pembahasan}

Uji validitas digunakan untuk mengetahui kelayakan butir-butir dalam suatu daftar pertanyaan dalam mendefinisikan suatu variabel. Daftar pertanyaan ini pada umumnya mendukung suatu kelompok variabel tertentu. Uji validitas dikatakan valid ketika hasil $r$ hitung $>r$ tabel, kemudian kita bandingkan dengan $r$ tabel di mana $\mathrm{df}=$ $\mathrm{n}-2$ dengan sig 5\%. Jika $\mathrm{r}$ hitung $>\mathrm{r}$ tabel maka valid. Hasil pengolahan data menggunakan SPSS disajikan pada tabel berikut ini: 
Tabel 1. Hasil Uji Validitas

\begin{tabular}{|c|c|c|c|}
\hline Variabel & r hitung & $\mathrm{r}$ tabel $(5 \%)$ & Keterangan \\
\hline Pertanyaan 1 & 0.4483 & 0.159 & Valid \\
\hline Pertanyaan 2 & 0.5505 & 0.159 & Valid \\
\hline Pertanyaan 3 & 0.6098 & 0.159 & Valid \\
\hline Pertanyaan 4 & 0.4151 & 0.159 & Valid \\
\hline Pertanyaan 5 & 0.2849 & 0.159 & Valid \\
\hline Pertanyaan 6 & 0.3756 & 0.159 & Valid \\
\hline Pertanyaan 7 & 0.3275 & 0.159 & Valid \\
\hline Pertanyaan 8 & 0.3399 & 0.159 & Valid \\
\hline Pertanyaan 9 & 0.4652 & 0.159 & Valid \\
\hline Pertanyaan 10 & 0.4308 & 0.159 & Valid \\
\hline Pertanyaan 11 & 0.4950 & 0.159 & Valid \\
\hline Pertanyaan 12 & 0.1843 & 0.159 & Valid \\
\hline Pertanyaan 13 & 0.4865 & 0.159 & Valid \\
\hline Pertanyaan 14 & 0.3410 & 0.159 & Valid \\
\hline Pertanyaan 15 & 0.1704 & 0.159 & Valid \\
\hline Pertanyaan 16 & 0.1688 & 0.159 & Valid \\
\hline Pertanyaan 17 & 0.2632 & 0.159 & Valid \\
\hline Pertanyaan 18 & 0.3196 & 0.159 & Valid \\
\hline Pertanyaan 19 & 0.4688 & 0.159 & Valid \\
\hline Pertanyaan 20 & 0.1831 & 0.159 & Valid \\
\hline
\end{tabular}

Sumber: Data primer yang diolah 2021

Berdasarkan Tabel satu menunjukkan bahwa dengan menggunakan jumlah responden sebanyak 159 maka nilai $\mathrm{r}_{\text {tabel }}$ dapat diperoleh melalui tabel $r$ product moment pearson dengan $d f$ (degree of freedom) $=\mathrm{n}-2$, jadi $\mathrm{df}=159-2=157$, maka $\mathrm{r}_{\text {tabel }}$ terdekat $=0,159$. Butir pertanyaan dikatakan valid karena nilai $r_{h i t u n g}>r_{\text {tabel }}$. 


\section{Uji Reliabilitas}

Reliabilitas merupakan ukuran suatu kestabilan dan konsistensi responden dalam menjawab hal yang berkaitan dengan konstruk-konstruk pertanyaan yang merupakan dimensi suatu variabel dan disusun dalam suatu bentuk kuesioner. Uji reliabilitas dapat dilakukan secara bersama- sama terhadap seluruh butir pertanyaan. Jika nilai Alpha $>0,60$ maka reliable.

Tabel 2. Hasil Uji Reliabilitas

\begin{tabular}{|l|c|c|}
\hline Variabel & Hasil & Keterangan \\
\hline Gaya hidup & 0,726 & Reliabel \\
\hline Kepribadian & 0,689 & Reliabel \\
\hline Literasi keuangan & 0,656 & Reliabel \\
\hline Pengelolaan keuangan & 0,767 & Reliabel \\
\hline
\end{tabular}

Sumber: Data primer yang diolah 2021

Berdasarkan Tabel dua menunjukkan bahwa hasil uji reliabilitas untuk semua butir jawaban kuesioner dapat diketahui bahwa masing-masing variabel memiliki cronbach alpha lebih dari 0,60. Variabel gaya hidup sebesar 0,726, kepribadian sebesar 0,689, pendapatan, literasi keuangan sebesar 0,656 dan pengelolaan keuangan sebesar 0,767. Maka variabel gaya hidup, pendapatan, kepribadian, literasi keuangan dan pengelolaan keuangan dapat dikatakan reliabel.

\section{Uji Asumsi Klasik}

1) Uji Multikolinieritas

Uji multikolinieritas digunakan untuk melihat ada tidaknya hubungan yang kuat antar variabel bebas. Untuk menguji apakah terjadi multikolinieritas atau tidak terjadi multikolinearitas dengan melihat nilai tolerance dan VIF (Variance Inflation Factor) dengan bantuan program SPSS. Jika nilai tolerance $>0,01$ dan VIF $<10,00$ maka tidak terjadi multikolinieritas.

Tabel 3. Hasil Uji Multikolinearitas

\begin{tabular}{|c|c|c|c|c|c|c|c|}
\hline \multicolumn{8}{|c|}{ Coefficients $^{\mathrm{a}}$} \\
\hline \multicolumn{2}{|c|}{ Model } & \multirow{2}{*}{\begin{tabular}{|l} 
Standardized \\
Coefficients \\
Beta \\
\end{tabular}} & \multirow[t]{2}{*}{$\mathrm{t}$} & \multirow[t]{2}{*}{ Sig. } & \multicolumn{3}{|c|}{$\begin{array}{l}\text { Collinearity } \\
\text { Statistics }\end{array}$} \\
\hline & & & & & Tole & nce & VIF \\
\hline \multirow[t]{5}{*}{1} & (Constant) & & & 4.499 & .000 & & \\
\hline & Gaya Hidup & .312 & & 3.375 & .001 & .622 & 1.607 \\
\hline & Pendapatan & .167 & & 1.946 & .053 & .719 & 1.391 \\
\hline & Kepribadian & .052 & & .612 & .542 & .745 & 1.342 \\
\hline & Literasi Keuangan & -.143 & & -1.782 & .077 & .824 & 1.213 \\
\hline
\end{tabular}

Sumber : Data primer yang diolah 2021 
Berdasarkan Tabel tiga menunjukkan hasil tampilan output SPSS pengujian Multikolinieritas menunjukan bahwa tidak terjadi gejala multikolinieritas pada semua variabel bebas (variabel independen) model regresi yang digunakan yaitu literasi keuangan, gaya hidup dan pendapatan karena semua variabel independen menunjukan nilai tolerance $>0,10$ dan $\mathrm{VIF}<10,00$.

2) Uji Heterokedastisitas

Heterokedastisitas adalah yang mana dalam model tidak terjadi ketidaksamaan variansi dari residual pada satu pengamatan ke pengamatan yang lain. Cara memprediksi ada atau tidaknya heterokedastisitas pada suatu model dapat dilihat pada uji gletser. Hasil uji heterokedastisitas yang diperoleh dalam penelitian ini bisa dilihat sebagai berikut :

Tabel 4. Hasil uji Heterokedastisitas (Gletser)

\begin{tabular}{|c|c|c|c|c|c|}
\hline \multicolumn{6}{|l|}{ Coefficients $^{\mathrm{a}}$} \\
\hline \multirow[t]{2}{*}{ Model } & \multicolumn{2}{|c|}{$\begin{array}{l}\text { Unstandardized } \\
\text { Coefficients }\end{array}$} & \multirow{2}{*}{$\begin{array}{c}\text { Standardized } \\
\text { Coefficients }\end{array}$} & \multirow[t]{2}{*}{$\mathrm{t}$} & \multirow[t]{2}{*}{ Sig. } \\
\hline & \begin{tabular}{l|l}
$\mathrm{B}$ \\
\end{tabular} & Std. Error & & & \\
\hline (Constant) & -.154 & .790 & & -.195 & .846 \\
\hline Gaya Hidup & -.069 & .051 & -.135 & -1.352 & .178 \\
\hline Pendapatan & .148 & .064 & .214 & 2.306 & .022 \\
\hline Kepribadian & -.052 & .050 & -.096 & -1.055 & .293 \\
\hline Literasi Keuangan & .066 & .049 & .117 & 1.345 & .181 \\
\hline
\end{tabular}

Sumber: Data primer yang diolah 2021

Berdasarkan Tabel empat menunjukkan dari hasil uji heterokedasitas dengan menggunakan uji gletser nilai signifikansi (sig) untuk variabel X1 gaya hidup sebesar $0.178>0,05$, variabel X2 pendapatan sebesar .022>0,05, variabel X3 kepribadian sebesar $0.293>0,05$ dan variabel X4 literasi keuangan sebesar 0.181> 0,05 Bisa disimpulkan terbebas dari gejala heterokedasitas.

3) Uji Normalitas

Uji normalitas digunakan untuk menguji apakah nilai residual dari regresi terdistribusi secara normal atau tidak. Model regresi yang baik adalah yang memiliki nilai residual yang terdistribusi normal. Dasar pengambilan keputusan uji normalitas dengan grafik histogram. 
Tabel 5. Hasil uji Normalitas

\begin{tabular}{|c|c|c|}
\hline \multicolumn{3}{|c|}{ One-Sample Kolmogorov-Smirnov Test } \\
\hline & & Unstandardized Residual \\
\hline \multicolumn{2}{|l|}{$\mathrm{N}$} & $\begin{array}{rr}159 \\
\end{array}$ \\
\hline \multirow[t]{2}{*}{ Normal Parameters ${ }^{\mathrm{a}, \mathrm{b}}$} & Mean & .0000000 \\
\hline & Std. Deviation & 1.24603188 \\
\hline \multirow[t]{3}{*}{ Most Extreme Differences } & Absolute & .103 \\
\hline & Positive & .103 \\
\hline & Negative & -.054 \\
\hline \multicolumn{2}{|l|}{ Kolmogorov-Smirnov Z } & 1.300 \\
\hline \multicolumn{2}{|l|}{ Asymp. Sig. (2-tailed) } & .068 \\
\hline
\end{tabular}

Sumber : Data primer yang diolah 2021

Berdasarkan tabel lima menunjukkan hasil dari SPSS uji normalitas, dimana hasil uji One-Sample Kolmogorov-Smirnov Test dengan nilai signifikansi sebesar 0.068 lebih besar dari 0.05 artinya data berdistribusi normal. Selanjutnya, dapat disimpulkan bahwa model regresi memenuhi asumsi uji normalitas.

4) Uji Regresi Berganda

Suatu teknik yang digunakan untuk membangun suatu persamaan yang menghubungkan antara variabel bebas dan variabel terikat. Untuk mendapatkan suatu persamaan regresi yang harus dilakukan adalah pertama mengumpulkan data dari variabel-variabel yang akan dilihat hubungannya, kemudian membuat gambar titiktitik kombinasi $\mathrm{Y}$ dan $\mathrm{X}$ dalam sistem koordinat yang biasa dikenal scatterplot dapat dibayangkan bentuk kurva yang sesuai dengan kombinasi X dan Y. Persamaan regresi dalam penelitian ini dapat dijelaskan sebagai berikut :

Tabel 6. Hasil Uji Regresi Berganda

\begin{tabular}{|c|c|c|c|c|c|}
\hline \multicolumn{6}{|l|}{ Coefficients $^{\mathrm{a}}$} \\
\hline \multirow[t]{2}{*}{ Model } & \multicolumn{2}{|c|}{ Unstandardized Coefficients } & \multirow{2}{*}{$\begin{array}{l}\text { Standardized } \\
\text { Coefficients } \\
\text { Beta } \\
\end{array}$} & \multirow[t]{2}{*}{$\mathrm{t}$} & \multirow[t]{2}{*}{ Sig. } \\
\hline & B & Std. Error & & & \\
\hline (Constant) & 5.668 & 1.260 & & 4.499 & .000 \\
\hline Gaya Hidup & .274 & .081 & 312 & 3.375 & .001 \\
\hline Pendapatan & .200 & .103 & .167 & 2.946 & .053 \\
\hline Kepribadian & .049 & .079 & .052 & 2.612 & .042 \\
\hline Literasi Keuangan & .140 & .079 & .143 & 2.782 & .077 \\
\hline
\end{tabular}

Sumber: Data primer yang diolah 2021 
Berdasarkan tabel enam diatas dapat diketahui hasil analisis regresi berganda untuk variabel gaya hidup sebesar 3.375, variabel pendapatan sebesar 2.946, variabel kepribadian sebesar 2.612 dan variabel literasi keuangan sebesar 2.782. Sehingga model persamaan regresi yang diperoleh $\mathrm{Y}=3.375 \mathrm{X}+2.946 \mathrm{X}+$ $2.612 \mathrm{X}+2.782+\mathrm{e}$

Nilai konstan (a) sebesar 4.499 artinya jika variable gaya hidup (X1), pendapatan (X2) dan kepribadian (X3) dan literasi keuangan nilainya adalah 0 (nol), maka variable pengelolaan keuangan berada pada angka 4.499.

Koefisien regresi (X1) dari perhitungan linier berganda didapat nilai koefisien (b1) $=3.375$ ini berarti setiap ada peningkatan gaya hidup (X1) maka pengelolaan keuangan akan meningkat sebesar $37.3 \%$ dengan anggapan variabel pendapatan (X2), kepribadian (X3) dan literasi keuangan (X4) adalah konstan. Koefisien regresi (X2) dari perhitungan linier berganda didapat nilai koefisien (b2) $=2.946$ hal ini berarti setiap ada peningkatan pendapatan (X2) maka pengelolaan keuangan akan meningkat sebesar $94.6 \%$ dengan anggapan variable gaya hidup (X1), kepribadian (X3) dan literasi keuangan (X4) adalah konstan.

Koefisien regresi (X3) dari perhitungan linier berganda didapat nilai koefisien $(\mathrm{b} 3)=2.612$ hal ini berarti setiap ada peningkatan kepribadian (X3) maka pengelolaan keuangan akan meningkat sebesar $61.2 \%$ dengan anggapan variable gaya hidup (X1), pendapatan (X2) dan literasi keuangan (X4) adalah konstan.

Koefisien regresi (X4) dari perhitungan linier berganda didapat nilai koefisien $(b 4)=2.782$ hal ini berarti setiap ada peningkatan literasi keuangan (X3) maka perilaku manajemen keuangan akan meningkat sebesar $78.2 \%$ dengan anggapan variable gaya hidup (X1), pendapatan (X2) dan kepribadian (X3) adalah konstan.

\section{Uji Hipotesis}

1) Uji F

Uji $F$ atau koefisien regresi secara bersama-sama digunakan untuk menjawab pertanyaan-pertanyaan apakah digunakan variabel independen (gaya hidup, pendapatan, kepribadian, dan literasi keuangan) secara bersama-sama mempunyai pengaruh yang signifikan terhadap variabel dependen (pengelolaan keuangan) tenaga kerja muda di Kota Ampana. Hasil F-test pada output SPSS dapat dilihat pada tabel ANOVA, jika p-value (pada kolom sig) $<$ dari level of significant yang ditentukan, atau $\mathrm{F}$ hitung (pada kolom $\mathrm{F}$ ) $>\mathrm{F}$ tabel atau dengan asumsi berikut :

Apabila nilai signifikan $<0,05$ maka HO ditolak dan HA diterima. Artinya variabel independen secara bersama-sama berpengaruh terhadap variabel dependen.

Apabila nilai signifikan $>0,05$ maka $\mathrm{HO}$ diterima dan HA ditolak. Artinya variabel independen secara bersama-sama tidak berpengaruh terhadap variabel dependen. 
Tabel 7. Hasil Uji F

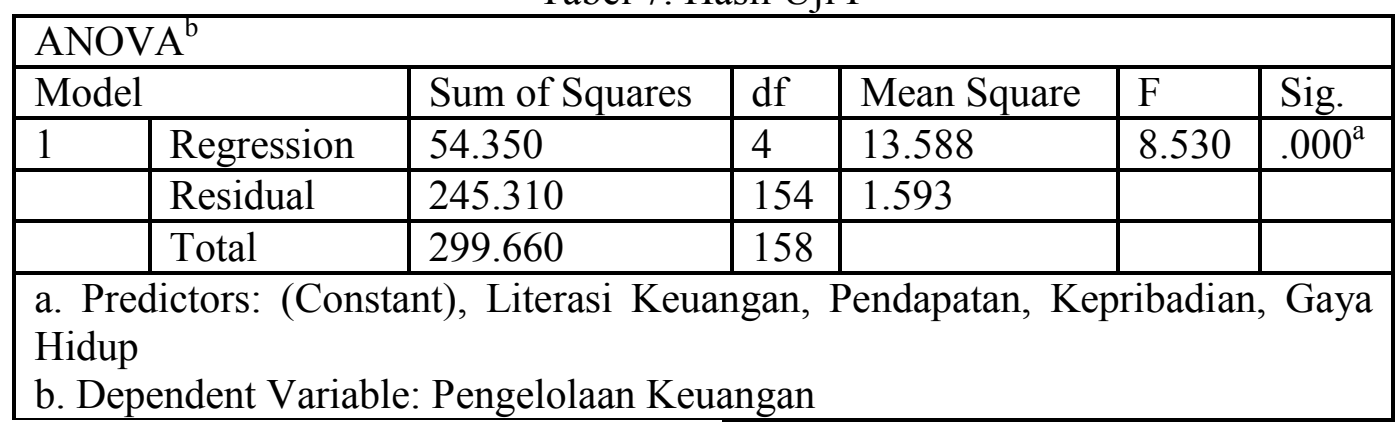

Sumber : Data penelitian yang diolah 2021

Berdasarkan Tabel 4.13 menunjukkan hasil output SPSS dalam tabel ANOVA menunjukan bahwa $F$ hitung sebesar 8.530 dengan $F$ tabel 2,37. Bahwa $F_{\text {hitung }}(8.530)$ $>\mathrm{F}_{\text {tabel }}(4 ; 159-4)(2,37)$ sedangkan signifikan $(0,000)<$ dari alpha pada taraf $10 \%$ atau 0,05 sehingga hipotesis yang dapat disimpulkan bahwa Ha diterima, artinya variabel independen (gaya hidup, pendapatan, kepribadian, dan literasi keuangan) berpengaruh positif dan signifikan terhadap variable dependen (pengelolaan keuangan) merupakan penjelasan dari variabel dependen (pengelolaan keuangan).

2) $U j i R^{2}$

Koefisien determinasi $\left(\mathrm{R}^{2}\right)$ bertujuan untuk menjelaskan seberapa besar kemampuan variabel independen (gaya hidup, pendapatan, kepribadian, dan literasi keuangan) terhadap variabel dependen (pengelolaan keuangan) dengan melihat R Square, nilai $\mathrm{R}$ Square baik jika diatas 0,5 .

Tabel 8. Hasil Uji $\mathrm{R}^{2}$

\begin{tabular}{|c|c|c|c|c|}
\hline \multicolumn{5}{|c|}{ Model Summary } \\
\hline Model & $\mathrm{R}$ & R Square & Adjusted R Square & Std. Error of the Estimate \\
\hline 1 & $.426^{\mathrm{a}}$ & .681 & .660 & 1.26211 \\
\hline
\end{tabular}

Sumber : Data penelitian yang diolah 2021

3) Uji t

Berdasarkan Tabel 4.14 diketahui bahwa nilai R Square sebesar 0.681, hal ini menunjukkan bahwa pengaruh variabel gaya hidup, pendapatan, kepribadian, dan literasi keuangan secara bersama-sama terhadap variabel pengelolaan keuangan adalah sebesar $68 \%$ sedangkan sisanya dipengaruhi oleh faktor lain sebesar $32 \%$. Uji parsial (uji t) menunjukan seberapa besarnya pengaruh masing-masing variable independent secara individual terhadap variable dependen, apakah hasilnya signifikan atau tidak.

Dengan asumsi berdasarkan Tabel 4.12 Hasil Uji t sebagai berikut:

Nilai $\mathrm{t}$ dari dari gaya hidup adalah $\mathrm{t}_{\text {hitung }}$ sebesar $3.375>\mathrm{t}_{\text {tabel }} 1,980$, dengan angka signifikan sebesar $0,001<0,05$. Hal ini menunjukan hipotesis yang mengatakan gaya 
hidup berpengaruh positif terhadap pengelolaan keuangan tenaga kerja muda di Kota Ampana adalah diterima.

Nilai $\mathrm{t}$ dari dari pendapatan adalah $\mathrm{t}_{\text {hitung }}$ sebesar $2.946>\mathrm{t}_{\text {tabel }} 1,980$, dengan angka signifikan sebesar $0.053<0,05$. Hal ini menunjukan hipotesis yang mengatakan pendapatan tidak berpengaruh positif terhadap pengelolaan keuangan tenaga kerja muda di Kota Ampana adalah ditolak.

Nilai $t$ dari dari kepribadian adalah $\mathrm{t}_{\text {hitung }}$ sebesar $2.612<\mathrm{t}_{\text {tabel }} 1,980$, dengan angka signifikan sebesar $0.042<0,05$. Hal ini menunjukan hipotesis yang mengatakan kepribadian berpengaruh positif dan signifikan terhadap pengelolaan keuangan tenaga kerja muda di Kota Ampana adalah diterima

Nilai $\mathrm{t}$ dari dari literasi keuangan adalah $\mathrm{t}_{\text {hitung }}$ sebesar $2.782<\mathrm{t}_{\text {tabel }} 1,980$, dengan angka signifikan sebesar $0.077<0,05$. Hal ini menunjukan hipotesis yang mengatakan literasi keuangan berpengaruh positif dan signifikan terhadap pengelolaan keuangan tenaga kerja muda di Kota Ampana adalah diterima

\section{Pembahasan Hasil Penelitian}

Pada pembahasan ini penulis menjelaskan hasil penelitian lapangan terhadap masingmasing variabel independen (literasi keuangan, gaya hidup dan pendapatan orang tua) variabel dependen (perilaku manajemen keuangan) maka dapat dijelaskan hal-hal sebagai berikut:

H1: Pengaruh Gaya Hidup Terhadap Pengelolaan Keuangan tenaga kerja muda di Kota Ampana

Pengujian hipotesis dapat dilihat pada uji t yang menunjukan bahwa pengaruh literasi keuangan terhadap perilaku manajemen keuangan santri signifikan, hal itu dapat dilihat dari nilai sig sebesar $0,001<0,10$. Hal tersebut juga didukung dengan nilai $t_{\text {hitung }}$ lebih besar dari nilai $t_{\text {tabel }}$. Nilai $t$ hitung yang didapat dari variable gaya hidup sebesar 3.375 $>\mathrm{t}$ tabel 1.980 dan $\beta=0.712$ atau $71 \%$ artinya bahwa gaya hidup (X1) berpengaruh positif dan signifikan terhadap perilaku manajemen keuangan (Y). Artinya seorang tenaga kerja muda dengan gaya hidup yang tinggi maka cenderung mempengaruhi pengelolaan keuangan tenaga kerja muda di Kota Ampana. Diperkuat dengan penelitian yang dilakukan oleh Nurul Amalia Putri, Diyan Lestari (2019) yang menyatakan bahwa gaya hidup gaya hidup berpengaruh secara parsial terhadap pengelolaan keuangan.

H2: Pengaruh Pendapatan Terhadap Pengelolaan Keuangan tenaga kerja muda di Kota Ampana

Pengujian hipotesis dapat dilihat pada uji $\mathrm{t}$ yang menunjukan bahwa pengaruh pendapatan terhadap pengelolaan keuangan tenaga kerja muda di Kota Ampana signifikan, hal itu dapat dilihat dari nilai sig sebesar $0.053<$ dari 0,10 . Hal tersebut juga didukung dengan nilai $t_{\text {hitung }}$ lebih besar dari nilai $t_{\text {tabel }}$. Nilai $t_{\text {hitung }}$ yang didapat dari variable literasi keuangan sebesar $2.946>t_{\text {tabel }} 1.980$. Dengan demikian hipotesis $\mathrm{H} 0$ ditolak dan $\mathrm{H} 1$ diterima yang artinya pendapatan dapat mempengaruhi pengelolaan keuangan tenaga kerja muda di Kota Ampana. Diperkuat dengan penelitian yang dilakukan oleh Baiq Fitri Arianti (2020) yang menyatakan bahwa Pendapatan berpengaruh terhadap literasi keuangan. 
H3: Pengaruh Kepribadian Terhadap Pengelolaan Keuangan tenaga kerja muda di Kota Ampana

Pengujian hipotesis dapat dilihat pada uji t yang menunjukan bahwa pengaruh literasi keuangan terhadap perilaku manajemen keuangan santri signifikan, hal itu dapat dilihat dari nilai sig sebesar $0.042<0,05$. Hal tersebut juga didukung dengan nilai $t_{\text {hitung }}$ lebih besar dari nilai $t_{\text {tabel }}$. Nilai $t$ hitung yang didapat dari variable Kepribadian sebesar sebesar $2.612<\mathrm{t}$ tabel 1.980 dan $\beta=0.652$ bernilai positif. Artinya kepribadian berpengaruh positif dan signifikan terhadap pengelolaan keuangan tenaga kerja muda di Kota Ampana. Penelitian ini diperkuat dengan penelitian yang dilakukan oleh LD Gadi Djou (2019) yang menyatakan bahwa Terdapat pengaruh positif Kepribadian terhadap Perilaku Pengelolaan Keuangan pada pelaku UMKM di Kabupaten Ende.

H4: Pengaruh Literasi Keuangan Terhadap Pengelolaan Keuangan tenaga kerja muda di Kota Ampana

Pengujian hipotesis dapat dilihat pada uji t yang menunjukan bahwa pengaruh literasi keuangan terhadap perilaku manajemen keuangan santri signifikan, hal itu dapat dilihat dari nilai sig sebesar $0,077<0,05$. Hal tersebut juga didukung dengan nilai $t_{\text {hitung }}$ lebih besar dari nilai tabel. Nilai $t$ hitung yang didapat dari variable literasi keuangan sebesar sebesar $2.782<\mathrm{t}$ tabel 1.980 dan $\beta=.643$ bernilai positif. Artinya literasi keuangan berpengaruh positif dan signifikan pengelolaan keuangan tenaga kerja muda di Kota Ampana. Yang artinya semakin tinggi pengetahuan keuangan dan kemampuan seseorang dalam mengimplementasikan aspek-aspek keuangan yang salah satunya adalah pengetahuan dasar keuangan mencakup pengeluaran, asset, hutang dan risiko maka akan menghasilkan perilaku keuangan yang bijak dan pengelolaan keuangan yang efektif. Diperkuat dengan penelitian yang dilakukan oleh LD Gadi Djou (2019) Terdapat pengaruh positif literasi keuangan terhadap perilaku pengelolaan keuangan pada pelaku UMKM di Kabupaten Ende, Delyana Rahmawany Pulungan dan Hastina Febriaty (2018) literasi keuangan berpengaruh secara parsial terhadap perilaku konsumtif mahasiswa, Nurul Amalia Putri, Diyan Lestari (2019) literasi keuangan berpengaruh secara parsial terhadap pengelolaan keuangan, Penelitian Destyan Nurul Fatimah (2017) Literasi keuangan berpengaruh terhadap perilaku keuangan pribadi mahasiswa.

\section{Kesimpulan}

\section{Kesimpulan Dan Saran}

Berdasarkan rumusan masalah dan hasil pembahasan maka bab ini penulis menjelaskan hasil penelitian lapangan untuk menjawab hipotesis maka dapat disimpulkan sebagai berikut:

Pengaruh Gaya Hidup Terhadap Pengelolaan Keuangan tenaga kerja muda di Kota Ampana

Pengujian hipotesis dapat dilihat pada uji t yang menunjukan bahwa pengaruh literasi keuangan terhadap perilaku manajemen keuangan santri signifikan, hal itu dapat dilihat dari nilai sig sebesar $0,001<0,10$. Hal tersebut juga didukung dengan nilai $t_{\text {hitung }}$ lebih besar dari nilai $t_{\text {tabel }}$. Memiliki Nilai $t_{\text {hitung }}$ tertinggi pengaruhnya yang didapat dari variable gaya hidup sebesar $3.375>\mathrm{t}$ tabel 1.980 dan $\beta=0.712$ atau $71 \%$ 
artinya bahwa gaya hidup (X1) berpengaruh positif dan signifikan terhadap perilaku manajemen keuangan (Y).

Pengaruh Pendapatan Terhadap Pengelolaan Keuangan tenaga kerja muda di Kota Ampana

Pengujian hipotesis dapat dilihat pada uji $\mathrm{t}$ yang menunjukan bahwa pengaruh pendapatan terhadap pengelolaan keuangan tenaga kerja muda di Kota Ampana signifikan, hal itu dapat dilihat dari nilai sig sebesar $0.053<$ dari 0,10 . Hal tersebut juga didukung dengan nilai $t_{\text {hitung }}$ lebih besar dari nilai $t_{\text {tabel }}$. Memiliki Nilai $t_{\text {hitung }}$ tertinggi kedua pengaruhnya yang didapat dari variable literasi keuangan sebesar $2.946>t_{\text {tabel }}$ 1.980. Dengan demikian pendapatan dapat mempengaruhi pengelolaan keuangan tenaga kerja muda di Kota Ampana.

Pengaruh Kepribadian Terhadap Pengelolaan Keuangan tenaga kerja muda di Kota Ampana

Pengujian hipotesis dapat dilihat pada uji t yang menunjukan bahwa pengaruh literasi keuangan terhadap perilaku manajemen keuangan santri signifikan, hal itu dapat dilihat dari nilai sig sebesar $0.042<0,05$. Hal tersebut juga didukung dengan nilai $\mathrm{t}_{\text {hitung }}$ lebih besar dari nilai $\mathrm{t}_{\text {tabel }}$. Memiliki Nilai $\mathrm{t}_{\text {hitung }}$ terendah pengaruhnya yang didapat dari variable Kepribadian sebesar sebesar $2.612<$ t tabel 1.980 dan $\beta=0.652$ bernilai positif. Artinya kepribadian berpengaruh positif dan signifikan terhadap pengelolaan keuangan tenaga kerja muda di Kota Ampana.

Pengaruh Literasi Keuangan Terhadap Pengelolaan Keuangan tenaga kerja muda di Kota Ampana

Pengujian hipotesis dapat dilihat pada uji t yang menunjukan bahwa pengaruh literasi keuangan terhadap perilaku manajemen keuangan santri signifikan, hal itu dapat dilihat dari nilai sig sebesar $0,077<0,05$. Hal tersebut juga didukung dengan nilai $t_{\text {hitung }}$ lebih besar dari nilai $t_{\text {tabel }}$. Memiliki Nilai $t_{\text {hitung }}$ tertinggi ketiga pengaruhnya yang didapat dari variable literasi keuangan sebesar sebesar $2.782<\mathrm{t}_{\text {tabel }} 1.980$ dan $\beta$ $=.643$ bernilai positif. Artinya literasi keuangan berpengaruh positif dan signifikan pengelolaan keuangan tenaga kerja muda di Kota Ampana.

\section{Saran}

Penelitian ini memiliki keterbatasan terhadap sedikitnya variabel yang dioperasionalisasikan sebab masih ada faktor lain yang mempengaruhi pengelolaan keuangan tidak diketahui dalam penelitian ini dimana terlihat dari nilai $\mathrm{R}$ Square sebesar 32\% dengan demikian disarankan untuk penelitian selanjutnya agar menambahkan variabel lain untuk memperkaya dan mengetahui manajemen pengelolaan keuangan yang ideal khususnya bagi tenaga kerja kaum muda.

\section{Daftar Pustaka}

Ani Caroline Grigion Potrich Kelmara Mendes Vieira Wesley Mendes-Da-Silva , (2016),"Development of a financial literacy model for university students", Management Research Review, Vol. 39 Iss 3 pp. http://dx.doi.org/10.1108/MRR-06-2014-0143 
Azizah, N. S. (2020). Pengaruh literasi keuangan, gaya hidup pada perilaku keuangan pada generasi milenial. Prisma (Platform Riset Mahasiswa Akuntansi), 1(2), 92-101.

Arianti, B. F. (2020, November). PENGARUH FAKTOR PENDAPATAN, KARIR DAN PENGALAMAN KERJA TERHADAP TINGKAT LITERASI KEUANGAN. In PROSEDING SEMINAR NASIONAL AKUNTANSI (Vol. 3, No. 1).

Bialowolski, P., Cwynar, A., \& Weziak-Bialowolska, D. (2020). Financial management, division of financial management power and financial literacy in the family context-evidence from relationship partner dyads. International Journal of Bank Marketing.

BPS. (2020). Statistik Pemuda Indonesia. www.bps.go.id

Baroroh, Mis Alul. (2019). Pengaruh Literasi Keuangan, Gaya Hidup Dan Pendapatan Orang Tua Terhadap Perilaku Manajemen Keuangan Santri Di Pondok Pesantren Madrosatul Qur'anil Aziziyah Semarang. Skripsi. UIN Walisongo Semarang

Dewi, I. M., \& Purbawangsa, I. B. A. (2018). Pengaruh literasi keuangan, pendapatan serta masa bekerja terhadap perilaku keputusan investasi. E-Jurnal Ekonomi dan Bisnis Universitas Udayana, 7(7)

Djou, L. G. (2019). Analisis pengaruh literasi keuangan, sikap keuangan dan kepribadian terhadap perilaku pengelolaan keuangan UMKM di Kabupaten Ende. Magisma: Jurnal Ilmiah Ekonomi dan Bisnis, 7(2), 123-134.

Fatimah, D.N. (2017). Pengaruh literasi keuangan terhadap perilaku keuangan mahasiswa (perbandingan mahasiswa ekonomi dan non ekonomi). Skripsi. UIN Sunan Kalijaga Yogyakarta

Jill Bamforth, Charles Jebarajakirthy, Gus Maarten Geursen, "Undergraduates' responses to factors affecting their money management behaviour: some new insights from a qualitative study", Young Consumers, https://doi.org/10.1108/YC-11-2016-00645

Krisniawati, K., \& Zulkarnain, M. (2019). ANALISIS KINERJA KEUANGAN PADA PT. BANK MANDIRI (PERSERO) TBK. Ihtiyath: Jurnal Manajemen Keuangan Syariah, 3(1).

Miftah, M., \& Murtatik, S. (2020, January). Analisis Gaya Hidup dan Literasi Keuangan Terhadap Perilaku Mahasiswa dalam Cashless Society. In Konferensi Riset Nasional Ekonomi, Manajemen, dan Akuntansi I.

Nabilla, D. R. (2016). Pengaruh Pengetahuan Keuangan, Pendapatan Dan Gaya Hidup Terhadap Perilaku Pengelolaan Keuangan Profesional Muda Di Surabaya (Doctoral dissertation, STIE Perbanas Surabaya).

Ningrum, V., Putri, I. A. P., \& Ekaputri, A. D. POLA PENGELUARAN DAN GAYA HIDUP PENDUDUK MUDA KELAS MENENGAH: STUDI EMPIRIS PERKOTAAN DI JABODETABEK1.

Putri, N. A., \& Lestari, D. (2019). Pengaruh Gaya Hidup dan Literasi Keuangan Terhadap Pengelolaan Keuangan Tenaga Kerja Muda di Jakarta. Akurasi: Jurnal Riset Akuntansi dan Keuangan, 1(1), 31-42. 
Pulungan, D. R., \& Febriaty, H. (2018). Pengaruh gaya hidup dan literasi keuangan terhadap perilaku konsumtif mahasiswa. Jurnal Riset Sains Manajemen, 2(3), 103-110. Retrieved from http://ejurnal.id/index.php/jsm/article/view/173

Setyawan, W., \& Wulandari, S. (2020). Perilaku Manajemen Keuangan Mahasiswa Kelas Karyawan Di Cikarang. Jurnal Ilmu Manajemen Dan Bisnis, 11(1), 47-60.

Sharif, S. P., \& Naghavi, N. (2020). Family financial socialization, financial information seeking behavior and financial literacy among youth. AsiaPacific Journal of Business Administration.

Tanada, N., \& Setyawan, I. R. (2020). Penentu Perilaku Keuangan Karyawan Muda Di Jakarta Dengan Literasi Keuangan Sebagai Variabel Mediasi. Jurnal Manajerial Dan Kewirausahaan, 2(2), 344-350.

Waluyo, F. I. A., \& Marlina, M. A. E. PERAN LITERASI KEUANGAN DALAM PENGELOLAAN KEUANGAN MAHASISWA.

Wulansari, Novi. (2019). Pengaruh Pendapatan, Literasi Keuangan, Dan Sikap Keuangan Terhadap Kesejahteraan Keuangan Keluarga Desa Ketanjung Kecamatan Karanganyar Kabupaten Demak Melalui Perilaku Keuangan Sebagai Variabel Intervening. Skripsi. FEB Unes 